\title{
Insights into the Potential Mechanisms of JAK2V617F Somatic Mutation Contributing Distinct Phenotypes in Myeloproliferative Neoplasms
}

\author{
Panhong Gou $1,2, * \mathbb{D}$, Wenchao Zhang ${ }^{3}$ and Stephane Giraudier $1,2,4, *$ \\ Laboratoire UMRS-1131, Ecole doctorale 561, Université de Paris, 75010 Paris, France \\ INSERM UMR-S1131, Hôpital Saint-Louis, 75010 Paris, France \\ BFA, UMR 8251, CNRS, Université de Paris, 75013 Paris, France; zhangwch611@gmail.com \\ Service de Biologie Cellulaire, Hôpital Saint-Louis, AP-HP, 75010 Paris, France \\ * Correspondence: panhong.gou@inserm.fr (P.G.); stephane.giraudier@aphp.fr (S.G.)
}

check for updates

Citation: Gou, P.; Zhang, W.;

Giraudier, S. Insights into the

Potential Mechanisms of JAK2V617F Somatic Mutation Contributing Distinct Phenotypes in

Myeloproliferative Neoplasms. Int. J.

Mol. Sci. 2022, 23, 1013.

https://doi.org/10.3390/ijms

23031013

Academic Editor: Haifa

Kathrin Al-Ali

Received: 21 December 2021

Accepted: 13 January 2022

Published: 18 January 2022

Publisher's Note: MDPI stays neutral with regard to jurisdictional claims in published maps and institutional affiliations.

Copyright: (C) 2022 by the authors. Licensee MDPI, Basel, Switzerland. This article is an open access article distributed under the terms and conditions of the Creative Commons Attribution (CC BY) license (https:// creativecommons.org/licenses/by/ $4.0 /)$

\begin{abstract}
Myeloproliferative neoplasms (MPN) are a group of blood cancers in which the bone marrow (BM) produces an overabundance of erythrocyte, white blood cells, or platelets. Philadelphia chromosome-negative MPN has three subtypes, including polycythemia vera (PV), essential thrombocythemia (ET), and primary myelofibrosis (PMF). The over proliferation of blood cells is often associated with somatic mutations, such as JAK2, CALR, and MPL. JAK2V617F is present in 95\% of PV and 50-60\% of ET and PMF. Based on current molecular dynamics simulations of full JAK2 and the crystal structure of individual domains, it suggests that JAK2 maintains basal activity through self-inhibition, whereas other domains and linkers directly/indirectly enhance this self-inhibited state. Nevertheless, the JAK2V617F mutation is not the only determinant of MPN phenotype, as many normal individuals carry the JAK2V617F mutation without a disease phenotype. Here we review the major MPN phenotypes, JAK-STAT pathways, and mechanisms of development based on structural biology, while also describing the impact of other contributing factors such as gene mutation allele burden, JAK-STAT-related signaling pathways, epigenetic modifications, immune responses, and lifestyle on different MPN phenotypes. The cross-linking of these elements constitutes a complex network of interactions and generates differences in individual and cellular contexts that determine the phenotypic development of MPN.
\end{abstract}

Keywords: MPN; JAK2V617F

\section{Introduction \\ 1.1. Myeloproliferative Neoplasms}

The myeloproliferative neoplasms (MPN) are a heterogeneous group of disorders characterized by the implication of one or more of the myeloid lineages. The myeloproliferative disease was first defined by the hematologist William Dameshek in 1951 [1] and reclassified as blood cancer in 2008 by the World Health Organization (WHO) [2]. MPN arises in the hematopoietic stem cell (HSC) compartment due to a single HSC acquiring somatic mutations (the most frequent mutation in MPN is JAK2V617F) that give the mutant HSC a selective advantage over normal HSC, thereby promoting myeloid cell differentiation and producing a myeloproliferative phenotype. In 2016, WHO classified MPN into four categories, based on the Philadelphia chromosome. The Philadelphia chromosome-positive includes chronic myeloid leukemia (CML) as well as in a subset of acute lymphoblastic leukemia (ALL), and the Philadelphia chromosome-negative has three subtypes, including polycythemia vera (PV), essential thrombocythemia (ET), and primary myelofibrosis (PMF). Of these, the Philadelphia chromosome-negative ones are closely related to JAK2V617F.

Classical PV presentation comprises red blood cell mass increase, hematocrit (HCT) increase, and leukocyte count increase, frequently associated with splenomegaly and 
incidental myelofibrosis. The HCT of peripheral blood is not always representative of the true volume of red cells in PV patients. Plasma volume can also vary; genuine erythrocytosis is indistinguishable from pseudo-erythrocytosis related to plasma volume contraction. Diagnosis is usually reached when there is splenomegaly, leukocytosis, and thrombocytosis. The JAK2V617F mutation is present in at least $95 \%$ of PV patients [3-5]. If $\mathrm{PV}$ is suspected, but there is no JAK2V617F mutation, mutations in exon 12 of JAK2 should be searched. Clinically, a characteristic of $\mathrm{PV}$ is a high frequency of thrombotic events concomitant to MPN, usually happening at the early course of the disease. PV is an unstable disease and may evolve toward myelofibrosis or leukemia. Treatment consists of venesections, anti-proliferative therapy, or JAK2-targeting drugs. However, cytoreductive treatments like pipobroman or hydroxyurea not only do not eradicate the disease but have also been suggested to increase the progression rate to AML [6]. Ruxolitinib, a JAK2 inhibitor, has been recognized to induce hematological responses, but the reduction of the clonal development [7] due to this drug is not established. Interferon-alpha (IFN- $\alpha$ ) seems to be the safest treatment available to control leukocytosis, thrombocytosis, and extramedullary hematopoiesis and to control symptoms caused by inflammatory cytokines. It is also able to reduce the development of the clonal population [8].

ET primarily occurs in people older than 60 years. However, it can also be diagnosed in young people, especially females, with approximately $20 \%$ of ET diagnoses in people younger than 40 years [9-11]. ET patients present with thrombocytosis, develop persistent and progressive thrombocytosis, and, as in PV, arterial and/or venous thrombosis [12]. Splenomegaly and leukocytosis can also be found but is less frequently observed than it is in PV [13]. Diagnosis of ET is suggested when patients harbor a high platelet count. Bone marrow biopsy shows proliferative hematopoiesis mainly of the megakaryocyte lineage. More than $75 \%$ of mutations are associated with the targeting JAK2 transduction pathway ((JAK2V617F), calreticulin (CALR), or myeloproliferative leukemia virus (MPL); all these mutations induce constitutive JAK2-dependent signaling. ET patients do not suffer from a significant reduction in overall survival (OS) [14]; when effective treatments and management of the complications are prescribed, this pathology can lead to an OS of 20 years or more. However, in $10 \%$ of cases, ET patients will develop MF during evolution. Bone marrow proliferation, reticular fibers deposits, anemia, and age are the risk factors for poor ET evolution. In addition, AML transformation can also occur and the outcome of these secondary AMLs is poor. According to Europe Leukemia Net (ELN) recommendations, the goal of treatment for patients with PV and ET is to prevent first/recurrent thrombosis and bleeding while effectively controlling symptoms (e.g., hematocrit, splenomegaly, histologic changes, etc.) to minimize the risk of developing MF or AML.

Primary myelofibrosis is characterized by erythroid-megakaryocytic hyperplasia in the bone marrow, neo-angiogenesis, and osteosclerosis. The median age of PMF at diagnosis is over 60 years; only $17 \%$ of patients are younger than 50 . There is a male bias just as in PV (and not in ET) [15,16]. In PMF patients, common findings consist of anemia, fever, cachexia, bone pain, pruritus, splenomegaly, neutrophilia, and thrombocytosis. Immature granulocytes, nucleated red cells, and teardrop-shaped red cells in the blood are biological characteristics of this disorder. The bone marrow histology demonstrates magakaryocytosis with reticulin and/or collagen fibrosis grade 2 or 3 [17]. After relatively few years, 20\% of PMF progresses to AML. Patients who did not transform may also succumb to other complications, including cardiovascular disease and the effects of cytopenias such as bleeding or inflammation [18]. PMF pathogenic mutations are in JAK2V617F in 50-60\% of patients [19]. PMF therapy aims to improve survival and treat symptoms by preventing bone marrow failure and transformation to AML, treating common systemic symptoms, and preventing thrombohemorrhagic complications [20].

\subsection{JAK-STAT Pathway}

Janus kinase (JAK) is a non-receptor type of tyrosine protein kinase. The JAKs family consists of four isoforms containing JAK1, JAK2, JAK3, and TYK2. JAK2, as a member of 
the JAKs family, is highly homologous to the other members and is widely distributed in the cytoplasm of somatic cells. JAK2 is involved in signal transduction in the hematopoietic and immune systems and plays an essential role in the production of erythrocytes and activation of immune cells as well. Each of JAKs molecules comprises seven homologous domains (JH1-7) (Figure 1A), the carboxy-terminal JH1 (Jak-homology 1) is a catalytic site of the enzyme, whereas the amino terminal end (JH4-JH7) is known as the FERM domain (band 4.1, ezrin, radixin, moesin) and it is responsible for the binding of the kinase to the receptor. The JH3-JH4 domains of JAKs share high homology with the Src-homology-2 (SH2) domain, also known as the SH2 domain. JH2 (Jak-homology 2) shares high homology with JH1 but lacks enzymatic activity and is known as the pseudokinase region [21,22].

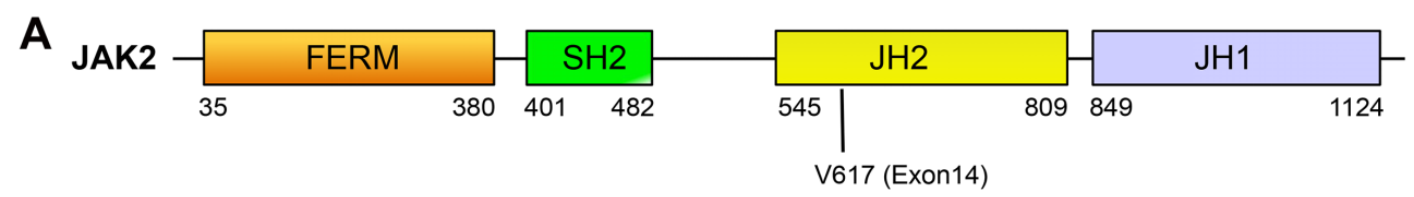

B
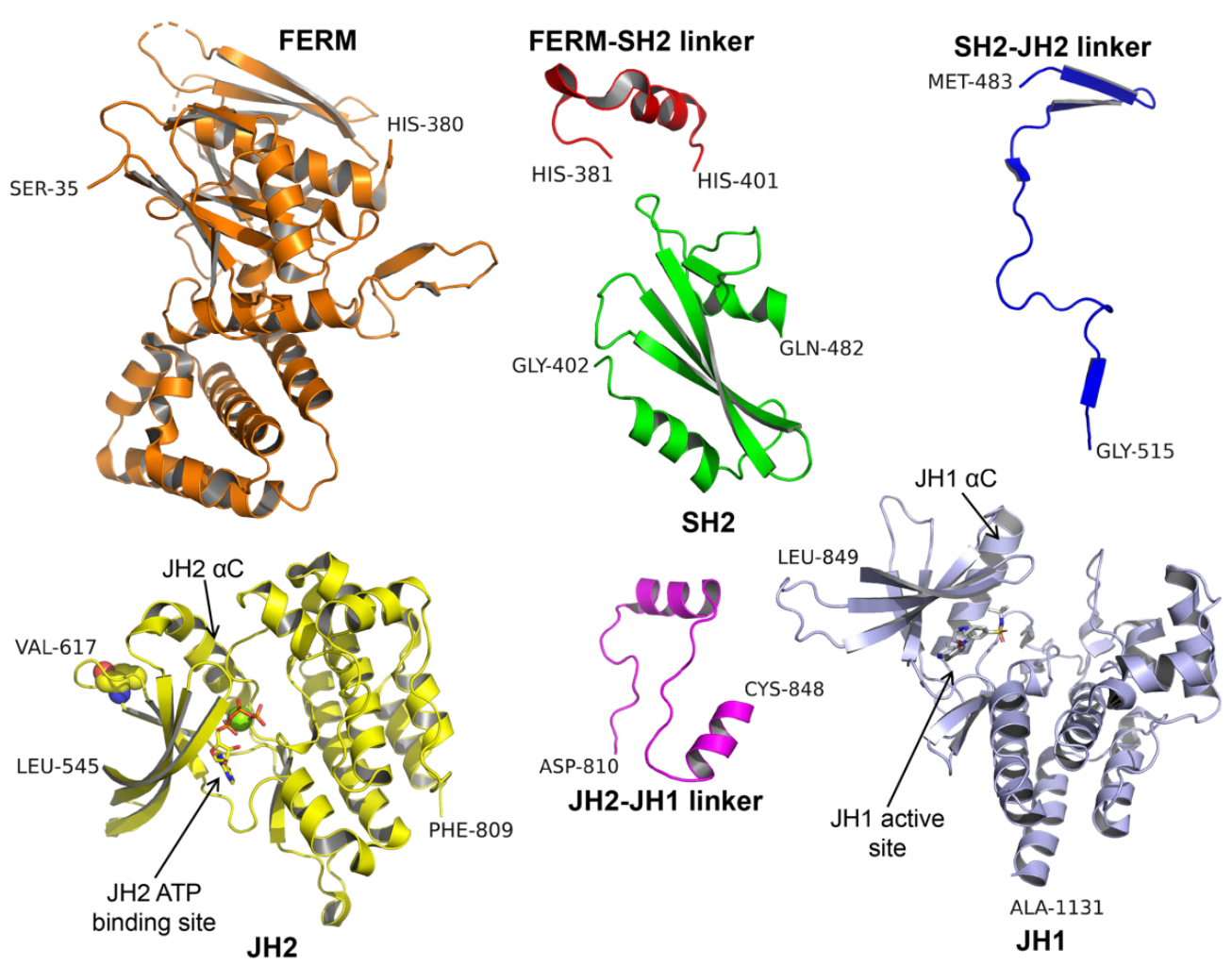

Figure 1. The structure of JAK2. (A) The domain organization of full length JAK2. (B) JAK2 domains and linkers were adapted from PDB and drawn in different colors. FERM (band 4.1, ezrin, radixin, moesin) domain colored in brown, $\mathrm{SH} 2$ (an Src homology 2) domain colored in green, JH2 (Jak-homology 2) domain colored in yellow, JH1 (Janus homology-1) domain colored in light blue, FERM-SH2 linker colored in red, SH2-JH2 linker colored in blue, and JH2-JH1 colored in magenta. FERM, FERM-SH2 linker, SH2, and SH2-JH2 linker (PDBID: 6E2Q); JH1 (PDBID: 6VNE); JH2 (PDBID: 5I4N); and JH1-JH2 linker (PDBID: 4OLI).

The STAT (signal transducer and activator of transcription) family contains seven subunits, including STAT1, STAT2, STAT3, STAT4, STAT5a, STAT5b, and STAT6. The activated JAKs can initiate specific STAT family members and interact with one another to constitute a complex regulatory network. The JAK-STAT system is one of the most important signaling pathways and involves three major components: (1) receptors, (2) JAK kinases, and (3) STAT [23,24]. The JAK2-STAT pathway, which is vital for communicating 
chemical signals from the outside of cells to the nucleus, is involved in cell division, cell death, tumor formation, and immunity [25].

In general, the cytokine receptor induces a conformational change upon ligand binding, resulting in the activation of receptor-associated JAK molecules and the phosphorylation of specific tyrosine residues within the intracellular domain of the cognate receptor. These phosphotyrosine residues on the receptor's intracellular domain with an src homology-2 (SH2) or a phosphotyrosine binding domain can serve as docking sites for downstream signaling proteins. Once these messengers bind to the receptor, they are phosphorylated by JAK kinase, leading to its activation (Figure 2). In this way, extracellular signals can be delivered to activate several downstream effector processes, including STAT transcription factors, the RAS/MAPK pathway, and the PI3K/AKT pathway.

JAK2 wild-type

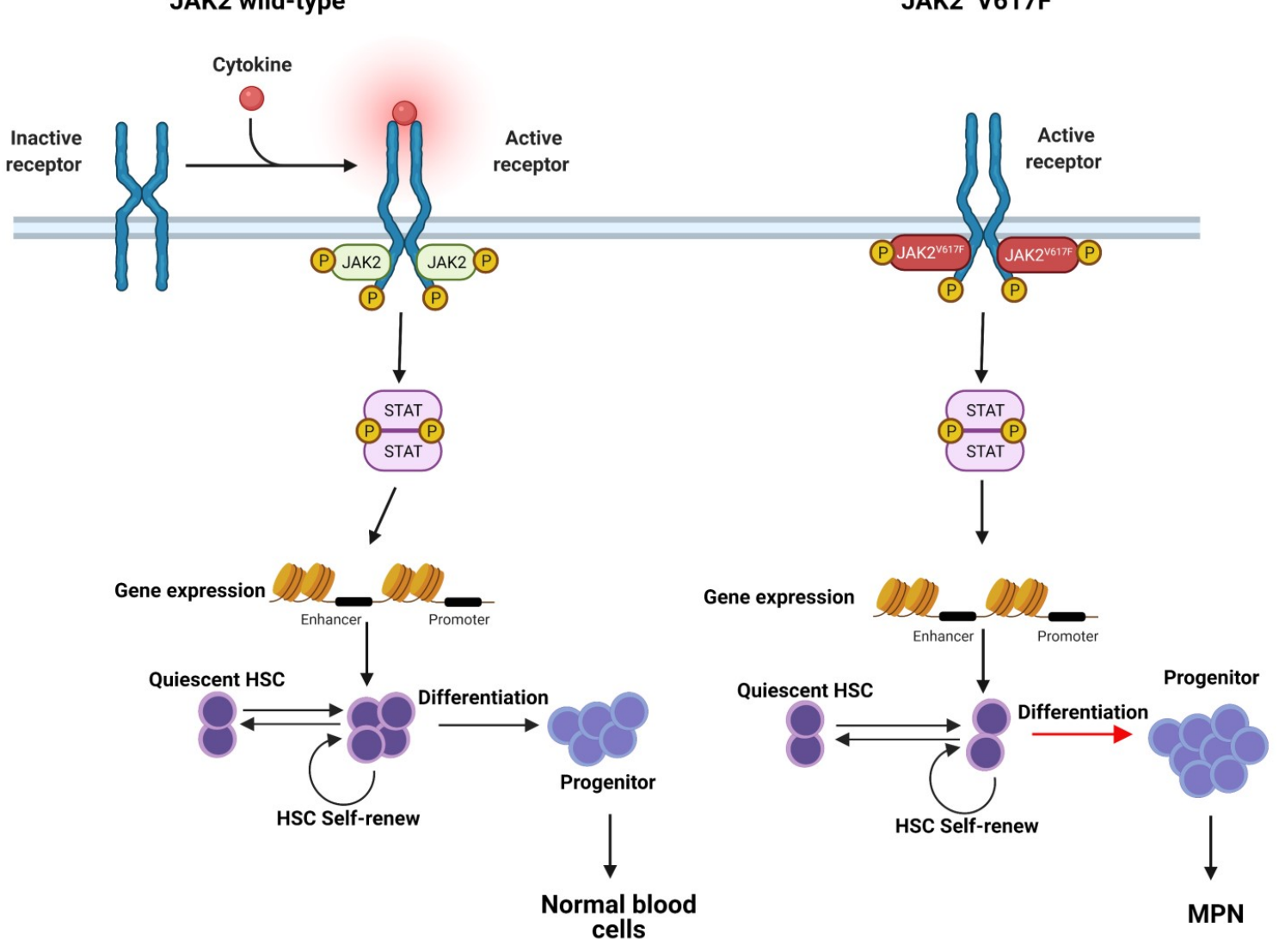

Figure 2. Typical and JAK2V617F induced dysregulated JAK2-STAT signaling. Normal JAK-STAT signaling is mediated by cytokines and growth factors, for instance, EPO and TPO, which maintain an ordered balance of cell proliferation and differentiation by self-renewal in HSC cell pool and are essential for normal blood cell formation (left panel). The JAK2V617F mutation causes JAK2 to be more sensitive to cytokines and consistently activates the JAK-STAT pathway. The over-activation of JAK2-STAT signaling alters the critical cell fate and leads to more progenitor cell development and further progression to MPN (right panel).

Abnormal cytokine signaling plays a vital role in the pathogenesis of MPN. In 1951, a study reported that MPN was caused by some unknown stimulus leading to excessive proliferation of BM cells [1]. Further studies revealed that hematopoietic progenitor cells from MPN patients exhibit hypersensitivity to cytokines such as erythropoietin (EPO), insulin-like growth factor-1 (IGF-1), IL-3, and granulocyte-macrophage colony-stimulating factor (GM-CSF), and were able to form erythroid and megakaryocyte colonies despite reduced or even absent cytokine levels (Figure 2) [26]. 


\section{The Role of JAK2V617F Contributes to MPN: Basis in Structural Biology}

\subsection{The Potential Mechanism of JAK2 Auto-Inhibition}

Currently, the tyrosine kinase of JAK2 does not have a complete structure and mainly consists of four fragment structures (JH1, JH2, SH2, and FERM) and three links (JH1-JH2 linker, JH2-SH2 linker, and SH2-FERM linker) connecting them (Figure 1). It is believed that the tyrosine kinase activity of JAK2 is primarily performed by the tyrosine kinase domain (JH1), perhaps involving a pseudokinase structural domain (JH2) as well, majorly phosphates the Ser523 and Try570. However, the detailed mechanism is not clear [27-30]. JAK2 kinase normal activity is activated by JH1 catalyzing two tyrosines (Try1007 and Try1008) situated on the active loop, phosphorylated Try1007 and Try1008 stabilizing the active state [31]. Hence, the trans-phosphorylation of these two tyrosines is a critical step for JAK activation [32]. Moreover, electrostatic interactions between JH1 and JH2 inhibit the tyrosine kinase activity of JH1 [33]. JH2 maintains the tyrosine kinase activity of JAK2 at a low basal level and maintains normal cellular activity; accordingly, it also indicated that JH2 has a tumor suppressor function [34].

The electrostatic interaction between JH2-JH1 is via two essential amino acids, phosphorylated in JH2, including Ser523 and Try570 [31,33]. The phosphorylation of Ser523 and Try570 is deemed to be an auto-phosphorylation of $\mathrm{JH} 2$ [35]. It has been also demonstrated that Ser523 is constitutively phosphorylated, whereas basal phosphorylation of Tyr570 is lower but increases significantly in response to cytokine stimulation in cells $[27,28]$, suggesting that JH1 may also be involved in the phosphorylation of Try570. Phosphorylation of Try570 by JH1 was also critical in the JH2-JH1 in vitro assay [36]. These results indicated Ser523 may be exclusively auto-phosphorylated through JH2, whereas phosphorylation of Try570 may be achieved through the combined phosphorylation of JH1 and JH2. In addition, recent molecular dynamics models of JH2-JH1 have identified that pSer523 and pTry570 play an essential role in stabilizing the JH2-JH1 interaction as well (Figure 3) [31,37,38]. Moreover, other residues, including Met600, Lys603, Leu604, Lys607, Arg683, Glu592, and Arg588 in JH1 and Lys883, Lys926, Arg922, Asp873, Try931, Pro933, and Arg947 in JH2, are also involved in stabilizing the JH2-JH1 interaction through salt bridging or van der Waals forces [31,38]. Mutations in these amino acids impair JH2-JH1 interactions and JH1 phosphorylation activity. Nevertheless, Ser523 and Try570 can only participate in the JH2-JH1 interaction in the phosphorylated state, suggesting the pivotal role of Ser523 and Try570 in regulating JAK2 kinase activity.

Stabilization of JH2-JH1 can affect the flexibility of JH1 and JH2 lobes, which in turn would suppress the phosphokinase activity of JH1 due to the shift of JH1; and JH2 lobes have an instrumental role in the transfer of phosphate groups during protein phosphorylation [39]. Simultaneously, JH1 and JH2 interaction disrupts the Lys882 and Glu898 interaction in JH1, resulting in "DFG flip" promotion in the active loop [40,41], which affects the catalytic activity of JH1. In a molecular dynamics model, the idea that the interaction of JH1 and JH2 produces a "DFG out" state (which is a JH1 inactivation state) was established [31]. The three other JAKs have no reported catalytic activity for JH2, possibly due to the absence of a phosphorylation site. Ser523 and Tyr570 are not conserved in JAKs [35], suggesting that JAK2 may be the only JAK kinase that possesses this negative regulatory mechanism.

In addition, a study with insect cells identified that the JH2-JH1 construct from JAK2 is not fully auto-inhibited [36], suggesting the interaction between JH2-JH1 and FERM$\mathrm{SH} 2$ is a component of full-length JAK2 protein auto-inhibition, and it appears that the interaction between FERM-JH2 and JH2-JH1 enhances JAK2 auto-inhibition. Recently, an interesting model of the active dimer was proposed based on the crystal dimerization of the FERM-SH2 of JAK2 bound to the erythropoietin receptor (EPOR) peptide [42], indicating that receptor-mediated formation of JAK2 FERM dimers is required for kinase activation with a separation of $120 \AA$ or more between $C$ termini and receptor transmembrane helices. A full-length JAK2 model indicates that the separation between receptor transmembrane helices in the active dimer is $\sim 40 \AA$ and $\sim 90 \AA$ in the inactive dimer [37], which is consistent 
with the other EPOR dimers [43,44]. Despite that, these findings implied that FERM is an integral part of JAK2 kinase activity.

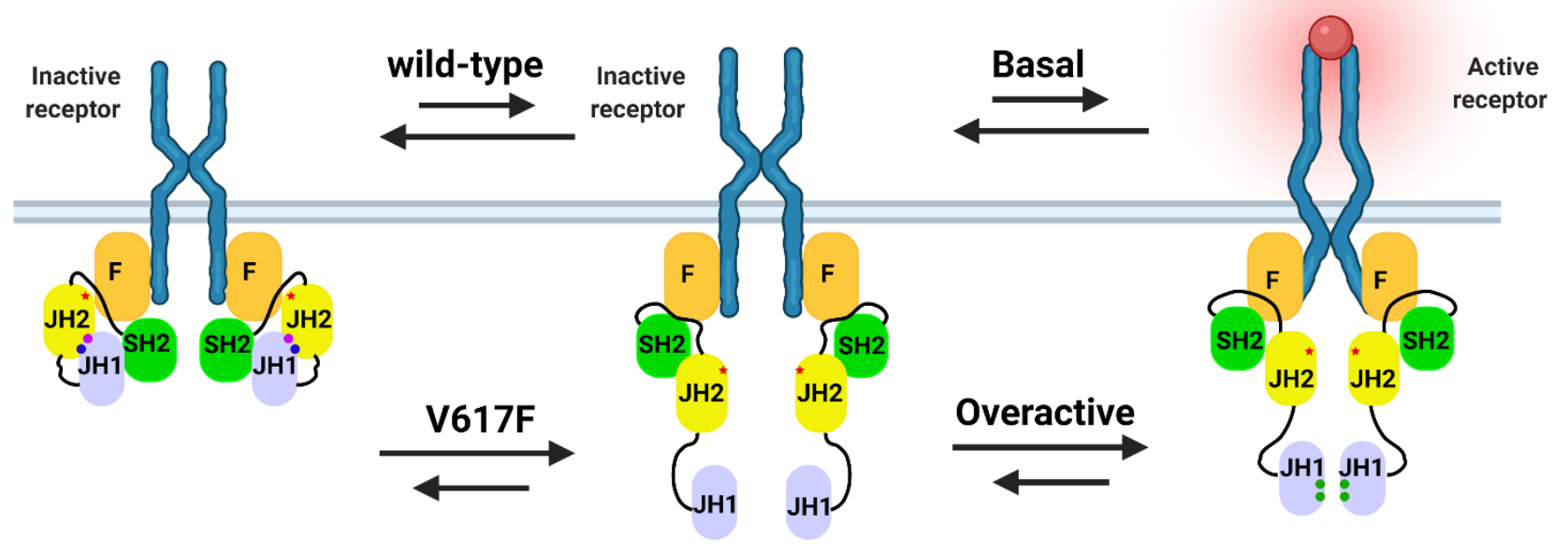

Figure 3. Model of the interactions between the domains of the JAK2 protein. The three main states of JAK2 include auto-inhibited state, unphosphorylated state, and active state. In the auto-inhibited state, the protein with phosphorylated S523 (pS523) and phosphorylated Y570 (pY570) are locked in the inactive conformation. The unphosphorylated state is a transition between the active and inactive conformations. In the active state, the two JAK2 molecules associated with a cytokine receptor dimer are maintained in positions that trans-phosphorylation of the JH1 activation loop, including Tyr1007 and Tyr1008. The pS523 is drawn as a blue dot, the pY570 is drawn as a red dot, the V617F mutation is drawn as a red star, and the pY1007/1008 is drawn as green dots.

\subsection{The Potential Mechanism of JAK2V617F Hyper-Activation}

The V617 mutation is not situated directly in the JH2-JH1 interface, but it is positioned close to the SH2-JH2 linker [31] and located at the FERM-JH2 interface as well [37]. The SH2-JH2 linker is essential for maintaining the basal state of JAK2 [45], and the FERM-JH2 interaction enhances the inhibition of JH1 phosphokinase activity via JH2. Therefore, the V617F mutation may disrupt the auto-inhibition of $\mathrm{SH} 2$ on $\mathrm{SH} 1$ by affecting the FERM-JH2, $\mathrm{SH} 2-\mathrm{JH} 2$, and SH1-JH2 interactions. It is also proposed that the V617F mutation not only affects the auto-inhibition of $\mathrm{SH} 2$ on $\mathrm{SH} 1$ but also stabilizes the active conformation of JAK2 through a novel molecular mechanism [38].

Initially, it was assumed that Ser523 and Try570 were auto-phosphorylated by $\mathrm{JH} 2$ either in cis or trans $[30,43]$. Moreover, the high-resolution crystal structure of JH2 and biochemical data revealed that Phe617 rotates the phenyl ring of Phe595 ( $\alpha \mathrm{C}$ in JH2) and induces a significant shift in the side chain position of the adjacent Phe594 [30]. The $\alpha \mathrm{C}$ residue is situated at the $\mathrm{JH} 2-\mathrm{JH} 1$ interface and along the line of the ATP binding pocket (Figure 1B), a region with importance in cytokine-induced kinase activation [44,46]. Phe617, Phe595, and Phe594 formalized $\pi$-stacking interactions, and perturbation of Phe594 slightly alters the side chain position of Lys581 [43], which is a conserved lysine and forms a salt bridge with conserved glutamine in $\alpha \mathrm{C}$ of JH2 [30]. A study identified the positions of Leu624 and Gln626, which are residues in the so-called "gatekeeper" position at the back of the ATP binding site, in the crystal structures of different ligands that appear to be compatible with the wild-type conformation of the JH2, but not with the V617F mutant conformation [45], due to steric clashes with Phe595 and Phe594, suggesting Phe617 and Phe595 interactions. Comparison of several available wild-types and V617F JH2 structures determined from various crystals reveal a distinct, stereotyped conformation of the $\beta 3-\alpha C$ (JH2) loop and $\alpha$-helix $(\alpha \mathrm{C})$ in the $\mathrm{N}$ lobe of JH2 (Figure 1B), where the main chain of 
the V617F mutant is shifted up to $6 \AA$ relative to the wild-type structures [45]. This may explain why the catalytic activity of JH2 is impaired in V617F and JH2 loses its catalytic activity and would be unable to phosphorylate Ser523 and Try570, thereby disrupting the SH2-JH1 interaction. Although it was later found that JH1 was also involved in the phosphorylation of Try570, the hypo-phosphorylated Ser523 and Try570 still reduced the stability of SH2-JH1.

Subsequently, molecular dynamics simulations were performed, including JH2-JH1 and full-length JAK2 kinases. The JH2-JH1 simulations revealed that the bulky phenylalanine at residue 617 destabilized the position of the $\mathrm{SH} 2-\mathrm{JH} 2$ linker between $\mathrm{JH} 2$ and $\mathrm{JH} 1$ and, as a result, the catalytically active conformation of $\alpha \mathrm{C}$ in JH1 was more stable in V617F than in wild-type JAK2. Also, in the simulations of double mutant V617F and F595A (located in the $\alpha \mathrm{C}$ of JH2), which inhibits V617F activity [45,47], the SH2-JH2 linker position is again stabilized between JH2 and JH1 [31]. In addition, the model based on JH2-JH1 auto-inhibitory interactions [31] suggests that V617 is close to the SH2-JH2 linker and affects the conformation of the SH2-JH2 linker. In the model, the SH2-JH2 linker is wedged between $\mathrm{JH} 2$ and $\mathrm{JH} 1$, and the $\mathrm{SH} 2-\mathrm{JH} 2$ linker is shown to play a role in maintaining the JAK2 basal activity. The full-length JAK2 kinase simulations results revealed that V617F is located at the center of the FERM-JH2 interface in both the active and inactive monomer models, indicating that the abnormally high constitutive activity of the V617F mutant may not arise as the V617F mutation both weakens the inactive conformation and stabilizes the active conformation of JAK2 [37].

Recently it has been shown that the wild-type JAK2 and JAK2V617F activation networks are distinct. A possible mechanism for the activation of JAK2 by V617F is also proposed based on biochemistry and crystals. Activation of JAK2V617F is thought to be triggered by mutant V617F and delivered via two switch residues E596 and F537. These activation events are two distinct molecular mechanisms that, when combined, will result in the vigorous activity of this mutant. The first mechanism is the disruption of the inhibitory interaction between $\mathrm{JH} 2$ and JH1 (pY570-K883). The second mechanism is the positive regulatory interaction of K857 (JH1 N-term) mediated by F537 (SH2-JH2 linker C-term) [38].

\section{The Role of JAK2V617F in Contributing to the MPN Phenotype}

The JAK2V617F mutation is detected in the majority of MPN patients, and it is also an indicator of MPN in clinical diagnostics. However, it is common to hear the question asked in the literature why the same JAK2V617F is present in patients with related but distinct MPN. More than fifteen years from the original description of JAK2V617F, attributing the MPN phenotype to JAK2 over-activation only seems to be an oversimplification of the complex molecular interactions regulating the JAK/STAT pathway. Several studies have found that JAK2V617F does not provide a proliferative advantage to the HSC compartment [48-51]. Xenotransplantation of BM cells from JAK2 mutant patients into recipient mice showed that JAK2 mutations did not benefit from self-renewal. In contrast, JAK2V617F-positive cells did not enhance self-renewal but expanded at the progenitor cell level $[52,53]$. These results suggest that the JAK2V617F mutation is not sufficient to initiate MPN disease in the absence of other factors involved. Although JAK2V617F is causal with MPN, the development of MPN is a complex process based on a combination of differences in individual and cellular backgrounds. On the basis of the current studies, JAK2V617F mutant allele burden, different signaling pathways, epigenetics modification, the immune system, and lifestyle may all be involved in JAK2V617F associated MPN development (see Table 1 and Figure 4). 
Table 1. JAK2V617F cooperate with different factors contribute to phenotype of MPN.

\begin{tabular}{|c|c|c|}
\hline & Factors & Comments \\
\hline \multirow{4}{*}{ JAK2V617F allele burden } & $\begin{array}{ll}\text { - } & \text { ET: homozygous } \\
\text { - } & \text { PV, ET: homozygous [54] } \\
\text { - } & \text { homo }=118(104 \mathrm{PV}, 14 \mathrm{ET}) \text { heter }=587, \\
& \text { WT }=257\end{array}$ & $\begin{array}{ll}\text { - } & \text { Increased cardiovascular events }(p=0.013) \\
\text { - } & \text { More frequent evolution into } \\
& \text { secondary myelofibrosis }\end{array}$ \\
\hline & ET: allele burden $>50 \% . n=165$ [55] & $\begin{array}{l}\text { Higher frequency of arterial thrombosis } \\
\text { and splenomegaly }\end{array}$ \\
\hline & PV: allele burden $>50 \% . n=43[56]$ & $\begin{array}{l}\text { More severe disease status } \\
\text { (higher } \mathrm{HCT}, \mathrm{RBC}, \mathrm{HGB} \text {, and } \mathrm{WBC} \text { ) }\end{array}$ \\
\hline & $\begin{array}{l}\text { MPN: homozygous. } \\
\text { heter }=45 \text { homo }=13\end{array}$ & $\begin{array}{l}\text { Higher hemoglobin, increased incidence of } \\
\text { pruritus, higher rate of fibrotic transformation }\end{array}$ \\
\hline \multirow{5}{*}{ Distinct signaling } & $\begin{array}{l}\text { RAS-ERK and phosphatidylinositol } \\
3 \text { kinase-AKT pathways }\end{array}$ & Dysregulated erythropoiesis in PV \\
\hline & IRS2 [58] & $\begin{array}{l}\text { Increased cell viability and reduced apoptosis in } \\
\text { JAK2-mutated cells }\end{array}$ \\
\hline & IGF1R inhibitory [59] & $\begin{array}{l}\text { Prevent the hematological disease in Jak2V617F } \\
\text { mutation mice }\end{array}$ \\
\hline & NT157 inhibits IRS1/2 and STAT3/5 [60] & \\
\hline & $\begin{array}{ll}\text { - } & \text { STAT3 pathway } \\
\text { - } & \text { STAT5, Ras/MEK/ERK and PI3K/Akt } \\
& {[61]}\end{array}$ & $\begin{array}{ll}\text { - } & \text { Enhance LAP expression } \\
\text { - } & \text { Stimulates cell proliferation }\end{array}$ \\
\hline \multirow{4}{*}{ Epigenetic modifiers } & TET2, ASXL1, IDH1, IDH2, IKZF1 and EZH2 & MPN-associated mutations \\
\hline & $\begin{array}{l}\text { TET2 12\%, ASXL1 5\%, DNMT3a 5\%, } \\
\text { EZH2 3\% and IDH1 1.5\% [62] }\end{array}$ & MPN \\
\hline & $\begin{array}{ll}\text { - } & \text { DNMT3A and TET2 } \\
\text { - } & \text { Mutation order of JAK2V617F and } \\
& \text { DNMT3A [63] }\end{array}$ & $\begin{array}{l}\text { - } \quad \text { Advantage to HSC/progenitor cells } \\
\text { - } \quad \text { Differences in MPN phenotype }\end{array}$ \\
\hline & $\begin{array}{ll}\text { - } & \text { ET: } \sim 4 \% \\
\text { - } & \text { PV: } 9.8-16 \% \\
\text { - } & \text { PMF:8-14\% }[64,65]\end{array}$ & TET2 in different phenotype of MPN \\
\hline \multirow{4}{*}{ Immune response } & TNFa, IFN $\alpha$, and IFNg pathways [66] & MPN development \\
\hline & $\mathrm{IFN} \alpha[67]$ & JAK2V617F increase molecular responses to \\
\hline & $\mathrm{TNF} \alpha[68]$ & Promote expansion of JAK2V617F cells in MPN \\
\hline & ROS and inflammatory factors [69] & influence MPN progression \\
\hline \multirow{4}{*}{ Effect of lifestyle } & Smoking [70] & Increase the risk of MPN \\
\hline & Coffee consumption [71] & Inversely associated with the risk of PV \\
\hline & Mediterranean dietary [72] & Decrease symptom burden in MPN \\
\hline & Obesity [73] & Elevate overall risk for MPN especially with ET \\
\hline
\end{tabular}




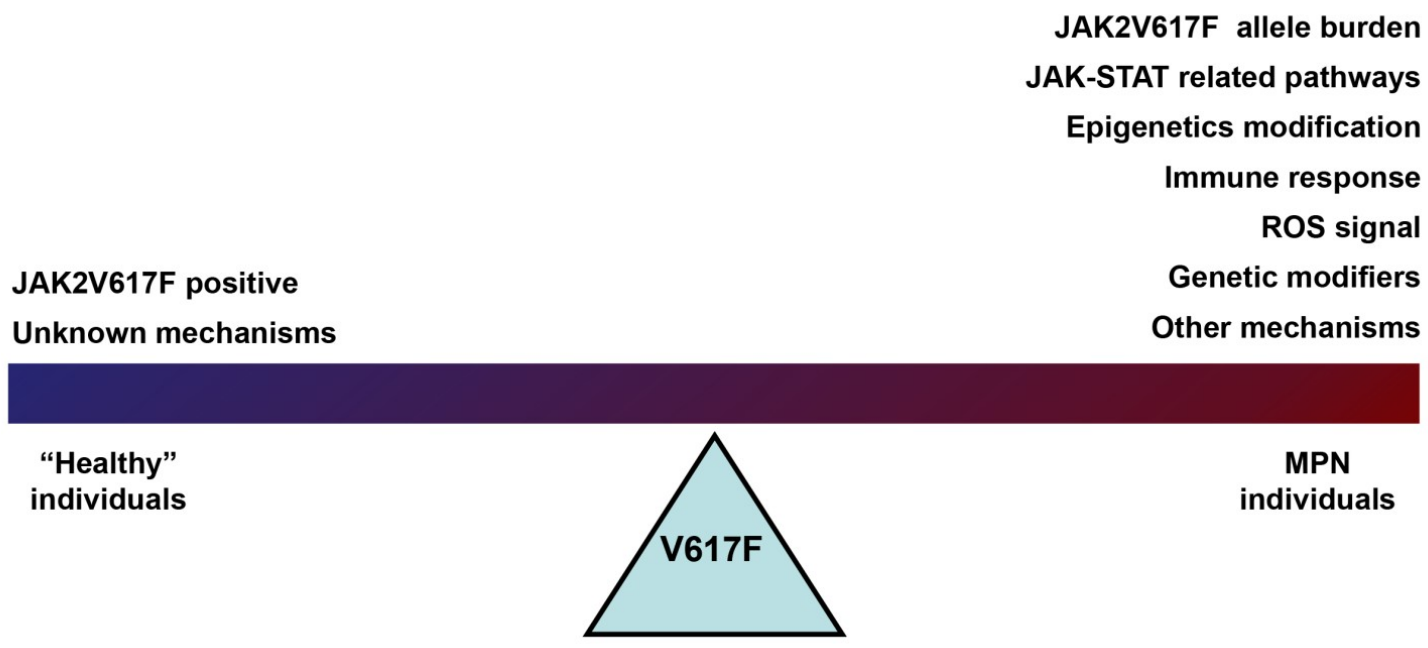

Figure 4. Model of JAK2V617F positive contributing to MPN phenotype.

\subsection{JAK2V617F Mutation Allele Burden}

Clinical data suggest that JAK2V617F mutations are present in $95 \%$ of patients with PV and 50-60\% of patients with ET and PMF [13,74-76], with homozygous JAK2V617F accounting for approximately $25-30 \%$ of patients with PV and $2-4 \%$ of patients with ET $[5,54,75]$. Vannucchi et al. found that JAK2V617F homozygosity could identify symptomatic myeloproliferative disease in patients with PV or ET. This study was based on 118 homologous JAK2V617F patients (including 104 PV, 14 ET), 587 JAK2V617F heterozygous patients, and 257 wild-type patients [54]. Antonioli et al. reported that the JAK2V617F mutant allele burden contributes to determining the clinical phenotype of patients in thrombocythemia [55]. Consistent with this, Kim et al. showed that the JAK2V617F mutant allele burden was positively associated with HCT, RBC, HGB, and WBC in patients with PV, and the mutant allele burden more significant than $50 \%$ reflects a severe disease state [77]. In addition, one hypothesis proposes that the ratio of mutant to wild-type JAK2 is critical to the phenotype, and this hypothesis has been validated by mouse models [52,57]. Tiedt et al. revealed that the mice developed an ET-like phenotype when JAK2V617F expression was lower than endogenous wild-type JAK2; the mice developed a PV-like phenotype with thrombocytosis and neutrophilic features when JAK2V617F levels were approximately equal to wild type JAK2, and higher levels of JAK2V617F caused a PV-like phenotype but no platelet formation [6]. The expression of homozygous JAK2V617F in the granulocyte compartment is much more common in PV than in ET [3]. In PV, JAK2V61F homozygous is correlated with the elevated HCT, WBC, splenomegaly, and lower platelets [78]. This hypothesis proposed that homozygous JAK2V617F drives the erythroid phenotype. A murine study showed that a low level of JAK2V617F drives thrombocytosis and a slight increase in HCT, which is the phenotype resembling ET, whereas higher level of JAK2V617F cause erythrocytosis and leukocytosis without thrombocytosis [57].These results suggest that lower levels of JAK2V617F are predominantly present in ET, whereas higher levels are present in PV.

\subsection{Distinct Signaling in JAK2V617F MPN Phenotype}

It has been indicated that the homodimeric type I cytokine receptor is necessary for optimal signaling by JAK2V617F $[79,80]$ and several signaling cascades activated by mutation JAK2V617F, including STAT5, MAPK, and PI3K pathways $[61,81,82]$. At least some aspects of the STAT5 pathway have been documented as necessary and sufficient for the MPN phenotype, in both in vitro and in vivo experiments [83-85]. Analysis of gene expression from normal and JAK2V617F heterozygous samples revealed that STAT5 activation is common in both PV and ET, whereas STAT1 activation is significantly pronounced in ET patients compared with PV patients [86]. Increased STAT1 activity promotes megakaryopoiesis and 
constrains erythropoiesis of cord blood-derived $\mathrm{CD} 34^{+}$cells, which support a clue for the phenotypic differences of specific MPN [87].

Insulin receptor substrate (IRS) proteins have reported involvement in myeloid neoplasms $[58,88]$, and they include adaptor proteins that could be activated by receptors participating in hematopoietic signaling, including IGF1R, EPOR, and TPOR $[59,60,89]$. Subsequent evidence indicates that IRS2 is associated with JAK2V617F induced malignant transformation and upregulation of IGF1R signaling, further inducing the MPN phenotype [60]. Reactive oxygen species (ROS) signaling also potentially contributes to the MPN phenotype [90]. It was shown in a mouse model that JAK2V617F induced ROS production, which would lead to genomic instability and disease occurrence [91]. In humans, ROS was increased in the hematopoietic cells of MPN patients compared to healthy individuals $[92,93]$. Smoking can further aggravate the impact of chronic inflammation and oxidative stress in MPNs, thereby contributing to genomic instability, subclone formation with MPN-disease progression, and the increased risk of second cancers [94]. High mobility group A2 (HMGA2, a non-histone architectural transcription factor) and let-7 (which negatively regulates HMGA2 expression) abnormal signaling activity can lead to a distinct clinical phenotype in MPN patients with JAK2V617F [95]. In addition, Uras et al. revealed that cyclin-dependent kinase 6 (CDK6) promotes MPN by enhancing cytokine production (in conjunction with NF-kB), activating leukemic stem cells, and preventing apoptosis [96]. Given that JAK2V617F is involved in multiple signaling regimes, most of the signaling mechanisms remain unclear.

\subsection{Epigenetic Modifiers in JAK2V617F MPN Phenotype}

Many MPN patients harbor somatic mutations in epigenetic regulators as well. For instance, DNA methylation (including TET2, DNMT3A, and IDH1/2) or chromatin structure (contains ASXL1 and EZH2) and accessory mutations in the regulators are proposed to affect MPN specific phenotypes $[63,97,98]$, promote progression, and induce phenotypic switching. In addition to driver mutations, alterations in the function of epigenetic regulators may also act as disease modifiers of MPN [99]. In addition, the order in which the mutations occur is critical. TET2 mutations altered the transcriptional program of JAK2V617F activation in a cell-intrinsic manner and are more frequently seen in the ET phenotype. Conversely, patients who acquire JAK2V617F first are more likely to develop PV [100]. TET2, ASXL1, and EZH2 mutations, either prior or subsequent to the acquisition of JAK2V617F, have been documented to affect hematopoietic stem and progenitor cell biology and clinical performance [62,63]. Moreover, Chen et al. demonstrated that loss of TET2 driving the clonal advantage of HSCs and expression of JAK2V617F led to an expanded population of downstream progenitors, which led to disease progression through a combination of effects [101]. Staehle et al. reported that the Jumonji domain containing 1C (JMJD1C), a histone demethylase, and it is a nuclear factor erythroid 2 (NFE2) target gene, may affect JAK2V617F driven myeloproliferative disease in mice [102]. Additionally, Peeken et al. showed that overexpression of NFE2 in MPN is associated with JAK2V617F phosphorylation of histone H3Y41 [103]. These results revealed that DNA methylation plays a crucial role in JAK2V617F associated MPN progression and it is probably the best described MPN in epigenetics mechanisms. McKenney et al. reported that mutations in epigenetic regulators, including mutations in isocitrate dehydrogenase 1 (IDH1), IDH2, and TET2, were identified in patients who progressed from MPN to AML [104,105]. In addition, co-expression of mutant IDH1 or IDH2 with JAK2V617F enhanced the progression of MPN in mice [103].

\subsection{Immune Response in JAK2V617F MPN Phenotype}

There is still a debate about the immune response in MPN, but some evidence has shown that immune response is critical in the progression of MPN. When analyzing the expression of the inflammatory genes in MPN patients, JAK2V617F heterozygous clones expressed p-selectin significantly higher than wild-type cells in the same patient [66]. In 
addition, tumor necrosis factor-a (TNFa), interleukin 6 (IL6), and interferon gamma (IFNg) signaling were detected enriched in heterozygous JAKV617F clones compared to the cells from healthy individuals [67]. The absence of TNFa in JAK2V617F transduced bone marrow cells completely abrogates the MPN phenotype in a mouse retroviral bone marrow transplant model [68]. Jacquelin et al. reported that the absence of DNMT3A enhanced TNFa signaling and inflammation in the JAK2V617F retroviral transduction and transplantation model, suggesting that MPN progression is a complicated multi-signal interaction [69]. Moreover, the role of NFkB/CDK6 in the regulation of inflammatory cytokines was further highlighted in the JAK2V617F transgenic mouse model [96]. Transformation and clonal evolution in MPN and other cancers were linked to genomic instability, which could be triggered by inflammatory cytokines $[106,107]$. Moreover, ROS is associated with genomic instability, point mutations, and chromosomal aberrations in patients with JAK2V617F positive MPN $[108,109]$, suggesting that ROS and inflammatory factors may cross interact to influence MPN progression. Holmström et al. demonstrated that a specific $\mathrm{CD} 8^{+}$cytotoxic $\mathrm{T}$ lymphocyte selectively recognized JAK2V617F mutant cells, suggesting that cancer immunotherapy is a potential new treatment modality for MPN [110].

\subsection{Effect of Lifestyle in JAK2V617F MPN}

The JAK2V617F mutation is one of the main acquired somatic mutations in MPN. However, the JAK2V617F mutation can be detected in the general population. Hinds et al. identified JAK2V617F carriers with a prevalence of $0.17 \%$ in the general population. The prevalence of JAK2V617F was associated with age and gender in this study [111]. It is well known that aging, smoking, and gender are the main risk factors for MPN. However, in addition to this, individual lifestyle also greatly influences the relationship between JAK2V617F and MPN. An NIH-AARP study found coffee consumption has an inverse relation to MPN risk where compared to low levels of caffeine intake. High intake of caffeine was also protective against risk for PV development [71]. The Mediterranean dietary pattern helps prevent common chronic diseases such as obesity and type 2 diabetes. A study also showed that the Mediterranean dietary help MPN patients decrease more than half of the symptom burden compared with MPN patients not following a Mediterranean diet [72]. It was also reported that the BMI was positively associated with the ET risk. Recently, the MOSAICC study showed that the obesity appeared to elevated overall risk for MPN, especially with ET [94]. These studies suggest that modification of lifestyle maybe a useful strategy to prevent the progression or transformation of MPN, especially for early stage MPN, and to reduce symptom burden.

\section{Summary and Discussion}

MPN is thought to arise in the HSC pool due to a single HSC acquiring a somatic mutation that alters the mutant HSC cell fate and promotes myeloid differentiation to produce a myeloproliferative phenotype. JAK2V617F is the most common mutation detected in the majority of patients with MPN and the mutant over-activates the JAK-STAT signaling pathway, which involves multiple signals mediating cell division and differentiation contributing to MPN progression. JAK2 inhibitors are also clinically effective against some types of MPN, suggesting the hyperactivity of JAK2 in MPN. Increasingly, studies demonstrated that JAK2V617F triggers MPN and requires the assistance of additional factors, for instance, different signaling pathway, epigenetic modification, and the immune response. The cross-linking of these signals forms a complex network of interactions and creates differences in individual and cellular contexts, determining the development of the MPN phenotype.

It is worth noting that studies revealed patients or 'healthy individuals' who are positive with JAK2V617F mutation who never develop MPN or other diseases [112,113] Recently, studies used state-of-the-art lineage tracing to determine the time of clonal amplification and disease progression after the acquisition of the JAK2V617F mutation [114,115] and suggested that the individuals who acquire the mutation in utero or early childhood 
could be diagnosed with disease decades later or even live with this mutation for life and without disease development. In addition, differences in individual immunity could likely have an influence, as previously described that specific CD8 ${ }^{+}$cytotoxic $\mathrm{T}$ lymphocytes selectively recognize JAK2V617F mutant cells [110]. In addition, a large number of homozygous JAK2V617F clones could be seen in male patients with PV, whereas female patients manifested ET, suggesting that gender may also regulate the phenotypic consequences of homozygosity [116]. Moreover, external factors may also be involved, for instance, a significantly higher risk of ET and unspecified MPN, but no PV was found in association with a history of smoking $[117,118]$. Furthermore, there were gender differences in the association of smoking history with MPN, as women with a history of smoking had a higher risk of developing MPN than men [66]. Importantly, it demonstrated that JAK2V617F positive ET and PV form a biological continuum [74], indicating that ET is an early stage of PV progression. Conversion to PV is rare in ET patients with the JAK2V617F mutation; nevertheless, it still occurs in some cases. A study showed that $5 \%$ of 422 JAK2V617F mutation ET patients converted to PV after 13 years [119]. The other study reported that there is $29 \%$ conversion rate of PV after 15 years in 466 ET patients with JAK2V617F mutation [120]. There is a study with mouse models showing that the phenotype of ET mouse models can convert to PV after several months of follow-up [121]. It was further demonstrated that the induction of MPN by JAKV617F requires the assistance of additional factors, including internal and external factors. In conclusion, other studies are necessary to investigate the contribution of JAK2V617F to the occurrence of MPN and provide more support for the treatment of MPN.

Author Contributions: Writing-original draft preparation, W.Z. and P.G.; writing-review and editing, W.Z. and P.G.; supervision, S.G.; project administration, S.G. All authors have read and agreed to the published version of the manuscript.

Funding: This research received no external funding.

Institutional Review Board Statement: Not applicable.

Informed Consent Statement: Not applicable.

Acknowledgments: This work was supported by running grants from Université de Paris, National Institute of Health and Medical Research (INSERM). P.G. and W.Z. were supported by the China Scholarship Council PhD fellowships. We thank Rose Ann Padua for English language manuscript reading and comments.

Conflicts of Interest: The authors declare no conflict of interest.

\section{References}

1. Dameshek, W. Some speculations on the myeloproliferative syndromes. Blood 1951, 6, 372-375. [CrossRef]

2. Tefferi, A.; Thiele, J.; Vardiman, J.W. The 2008 World Health Organization classification system for myeloproliferative neoplasms: Order out of chaos. Cancer 2009, 115, 3842-3847. [CrossRef]

3. Kralovics, R.; Passamonti, F.; Buser, A.S.; Teo, S.-S.; Tiedt, R.; Passweg, J.R.; Tichelli, A.; Cazzola, M.; Skoda, R.C. A Gain-ofFunction Mutation of JAK2 in Myeloproliferative Disorders. N. Engl. J. Med. 2005, 352, 1779-1790. [CrossRef]

4. $\quad$ Levine, R.L.; Wadleigh, M.; Cools, J.; Ebert, B.L.; Wernig, G.; Huntly, B.J.P.; Boggon, T.J.; Wlodarska, I.; Clark, J.J.; Moore, S.; et al. Activating mutation in the tyrosine kinase JAK2 in polycythemia vera, essential thrombocythemia, and myeloid metaplasia with myelofibrosis. Cancer Cell 2005, 4, 387-397. [CrossRef]

5. Baxter, E.J.; Scott, L.M.; Campbell, P.J.; East, C.; Fourouclas, N.; Swanton, S.; Vassiliou, G.S.; Bench, A.J.; Boyd, E.M.; Curtin, N.; et al. Acquired mutation of the tyrosine kinase JAK2 in human myeloproliferative disorders. Lancet 2005, 365, 1054-1061. [CrossRef]

6. Crisà, E.; Venturino, E.; Passera, R.; Prina, M.; Schinco, P.; Borchiellini, A.; Giai, V.; Ciocca Vasino, M.A.; Bazzan, M.; Vaccarino, A.; et al. A retrospective study on 226 polycythemia vera patients: Impact of median hematocrit value on clinical outcomes and survival improvement with anti-thrombotic prophylaxis and non-alkylating drugs. Ann. Hematol. 2010, 89, 691-699. [CrossRef]

7. Colafigli, G.; Scalzulli, E.; Pepe, S.; Di Prima, A.; Efficace, F.; Martelli, M.; Foà, R.; Breccia, M. The advantages and risks of ruxolitinib for the treatment of polycythemia vera. Expert Rev. Hematol. 2020, 13, 1067-1072. [CrossRef]

8. Lengfelder, E.; Berger, U.; Hehlmann, R. Interferon $\alpha$ in the treatment of polycythemia vera. Ann. Hematol. 2000, 79, 103-109. [CrossRef] 
9. Cortelazzo, S. Incidence and risk factors for thrombotic complications in a historical cohort of 100 patients with essential thrombocythemia. J. Clin. Oncol. 1990, 8, 556-562. [CrossRef]

10. Fenaux, P.; Simon, M.; Caulier, M.T.; Lai, J.L.; Goudemand, J.; Bauters, F. Clinical course of essential thrombocythemia in 147 cases. Cancer 1990, 66, 549-556. [CrossRef]

11. Tefferi, A.; Fonseca, R.; Pereira, D.L.; Clark Hoagland, H. A long-term retrospective study of young women with essential thrombocythemia. Mayo Clin. Proc. 2001, 76, 22-28. [CrossRef] [PubMed]

12. Carobbio, A.; Thiele, J.; Passamonti, F.; Rumi, E.; Ruggeri, M.; Rodeghiero, F.; Randi, M.L.; Bertozzi, I.; Vannucchi, A.M.; Antonioli, E.; et al. Risk factors for arterial and venous thrombosis in WHO-defined essential thrombocythemia: An international study of 891 patients. Blood 2011, 117, 5857-5859. [CrossRef]

13. Oh, S.T.; Gotlib, J. JAK2 V617F and beyond: Role of genetics and aberrant signaling in the pathogenesis of myeloproliferative neoplasms. Expert Rev. Hematol. 2010, 3, 323-337. [CrossRef] [PubMed]

14. Briére, J.B. Essential thrombocythemia. Orphanet J. Rare Dis. 2007, 2, 1-17. [CrossRef] [PubMed]

15. Cervantes, F.; Passamonti, F.; Barosi, G.; San Matteo, P. Life expectancy and prognostic factors in the classic BCR/ABL-negative myeloproliferative disorders. Leukemia 2008, 22, 905-914. [CrossRef]

16. Cervantes, F.; Dupriez, B.; Pereira, A.; Passamonti, F.; Reilly, J.T.; Morra, E.; Vannucchi, A.M.; Mesa, R.A.; Demory, J.L.; Barosi, G.; et al. New prognostic scoring system for primary myelofibrosis based on a study of the International working group for myelofibrosis research and treatment. Blood 2009, 113, 2895-2901. [CrossRef]

17. Barosi, G.; Mesa, R.A.; Thiele, J.; Cervantes, F.; Campbell, P.J.; Verstovsek, S.; Dupriez, B.; Levine, R.L.; Passamonti, F.; Gotlib, J.; et al. Proposed criteria for the diagnosis of post-polycythemia vera and post-essential thrombocythemia myelofibrosis: A consensus statement from the international working group for myelofibrosis research and treatment. Leukemia 2008, 22, 437-438. [CrossRef]

18. Tefferi, A. Primary myelofibrosis: 2019 update on diagnosis, risk-stratification and management. Am. J. Hematol. 2018, 93, 1551-1560. [CrossRef]

19. Ayalew Tefferi, W.V. Myeloproliferative neoplasms: Molecular pathophysiology, essential clinical understanding, and treatment strategies. J. Clin. Oncol. 2011, 29, 573-582. [CrossRef]

20. Barbui, T.; Barosi, G.; Birgegard, G.; Cervantes, F.; Finazzi, G.; Griesshammer, M.; Harrison, C.; Hasselbalch, H.C.; Hehlmann, R.; Hoffman, R.; et al. Philadelphia-negative classical myeloproliferative neoplasms: Critical concepts and management recommendations from European leukemiaNet. J. Clin. Oncol. 2011, 29, 761-770. [CrossRef]

21. Ferrao, R.; Lupardus, P.J. The Janus Kinase (JAK) FERM and SH2 domains: Bringing specificity to JAK-receptor interactions. Front. Endocrinol. (Lausanne) 2017, 8, 71. [CrossRef] [PubMed]

22. Toms, A.V.; Deshpande, A.; McNally, R.; Jeong, Y.; Rogers, J.M.; Kim, C.U.; Gruner, S.M.; Ficarro, S.B.; Marto, J.A.; Sattler, M.; et al Structure of a pseudokinase-domain switch that controls oncogenic activation of Jak kinases. Nat. Struct. Mol. Biol. 2013, 20, 1221-1224. [CrossRef] [PubMed]

23. Howell, M.D.; Kuo, F.I.; Smith, P.A. Targeting the Janus Kinase Family in Autoimmune Skin Diseases. Front. Immunol. 2019, 10, 2342. [CrossRef] [PubMed]

24. Williams, N.K.; Bamert, R.S.; Patel, O.; Wang, C.; Walden, P.M.; Wilks, A.F.; Fantino, E.; Rossjohn, J.; Lucet, I.S. Dissecting specificity in the Janus kinases: The structures of JAK-specific inhibitors complexed to the JAK1 and JAK2 protein tyrosine kinase domains. J. Mol. Biol. 2009, 387, 219-232. [CrossRef]

25. O'Shea, J.J.; Holland, S.M.; Staudt, L.M. JAKs and STATs in Immunity, Immunodeficiency, and Cancer. N. Engl. J. Med. 2013, 368, 161-170. [CrossRef]

26. Prchal, J.F.; Axelrad, A.A. Letter: Bone-marrow responses in polycythemia vera. N. Engl. J. Med. 1974, 290, 1382. [CrossRef]

27. Argetsinger, L.S.; Kouadio, J.-L.K.; Steen, H.; Stensballe, A.; Jensen, O.N.; Carter-Su, C. Autophosphorylation of JAK2 on Tyrosines 221 and 570 Regulates Its Activity. Mol. Cell. Biol. 2004, 24, 4955-4967. [CrossRef]

28. Feener, E.P.; Rosario, F.; Dunn, S.L.; Stancheva, Z.; Myers, M.G. Tyrosine Phosphorylation of Jak2 in the JH2 Domain Inhibits Cytokine Signaling. Mol. Cell. Biol. 2004, 24, 4968-4978. [CrossRef] [PubMed]

29. Ishida-Takahashi, R.; Rosario, F.; Gong, Y.; Kopp, K.; Stancheva, Z.; Chen, X.; Feener, E.P.; Myers, M.G. Phosphorylation of Jak2 on Ser523 InhibitsJak2-Dependent Leptin ReceptorSignaling. Mol. Cell. Biol. 2006, 26, 4063-4073. [CrossRef]

30. Mazurkiewicz-Munoz, A.M.; Argetsinger, L.S.; Kouadio, J.-L.K.; Stensballe, A.; Jensen, O.N.; Cline, J.M.; Carter-Su, C. Phosphorylation of JAK2 at Serine 523: A Negative Regulator of JAK2 That Is Stimulated by GrowthHormone and Epidermal Growth Factor. Mol. Cell. Biol. 2006, 26, 4052-4062. [CrossRef]

31. Shan, Y.; Gnanasambandan, K.; Ungureanu, D.; Kim, E.T.; Hammarén, H.; Yamashita, K.; Silvennoinen, O.; Shaw, D.E.; Hubbard, S.R. Molecular basis for pseudokinase-dependent autoinhibition of JAK2 tyrosine kinase. Nat. Struct. Mol. Biol. 2014, 21, 579-584. [CrossRef] [PubMed]

32. Feng, J.; Witthuhn, B.A.; Matsuda, T.; Kohlhuber, F.; Kerr, I.M.; Ihle, J.N. Activation of Jak2 catalytic activity requires phosphorylation of Y1007 in the kinase activation loop. Mol. Cell. Biol. 1997, 17, 2497-2501. [CrossRef]

33. McNally, R.; Li, Q.; Li, K.; Dekker, C.; Vangrevelinghe, E.; Jones, M.; Chène, P.; MacHauer, R.; Radimerski, T.; Eck, M.J. Discovery and Structural Characterization of ATP-Site Ligands for the Wild-Type and V617F Mutant JAK2 Pseudokinase Domain. ACS Chem. Biol. 2019, 14, 587-593. [CrossRef] [PubMed] 
34. Lupardus, P.J.; Ultsch, M.; Wallweber, H.; Kohli, P.B.; Johnson, A.R.; Eigenbrot, C. Structure of the pseudokinase-kinase domains from protein kinase TYK2 reveals a mechanism for Janus kinase (JAK) autoinhibition. Proc. Natl. Acad. Sci. USA 2014, 111, 8025-8030. [CrossRef] [PubMed]

35. Hubbard, S.R. Mechanistic insights into regulation of JAK2 tyrosine kinase. Front. Endocrinol. (Lausanne) 2018, 8, 1-7. [CrossRef] [PubMed]

36. Varghese, L.N.; Ungureanu, D.; Liau, N.P.D.; Young, S.N.; Laktyushin, A.; Hammaren, H.; Lucet, I.S.; Nicola, N.A.; Silvennoinen, O.; Babon, J.J.; et al. Mechanistic insights into activation and SOCS3-mediated inhibition of myeloproliferative neoplasm-associated JAK2 mutants from biochemical and structural analyses. Biochem. J. 2014, 458, 395-405. [CrossRef]

37. Ayaz, P.; Hammarén, H.M.; Raivola, J.; Sharon, D.; Hubbard, S.R.; Silvennoinen, O.; Shan, Y.; Shaw, D.E. Structural models of full-length JAK2 kinase. bioRxiv 2019, 3, 727727. [CrossRef]

38. Leroy, E.; Dusa, A.; Colau, D.; Motamedi, A.; Cahu, X.; Mouton, C.; Huang, L.J.; Shiau, A.K.; Constantinescu, S.N. Uncoupling JAK2 V617F activation from cytokine-induced signalling by modulation of JH2 $\alpha \mathrm{C}$ helix. Biochem. J. 2016, 473, 1579-1591. [CrossRef]

39. Liang, S.; Zhang, C.; Sarmiento, J.; Standley, D.M. Protein loop modeling with optimized backbone potential functions. J. Chem. Theory Comput. 2012, 8, 1820-1827. [CrossRef]

40. Nagar, B.; Hantschel, O.; Young, M.A.; Scheffzek, K.; Veach, D.; Bornmann, W.; Clarkson, B.; Superti-Furga, G.; Kuriyan, J Structural basis for the autoinhibition of c-Abl tyrosine kinase. Cell 2003, 112, 859-871. [CrossRef]

41. Shan, Y.; Seeliger, M.A.; Eastwood, M.P.; Frank, F.; Xu, H.; Jensen, M.; Dror, R.O.; Kuriyan, J.; Shaw, D.E. A conserved protonationdependent switch controls drug binding in the Abl kinase. Proc. Natl. Acad. Sci. USA 2009, 106, 139-144. [CrossRef] [PubMed]

42. Ferrao, R.D.; Wallweber, H.J.A.; Lupardus, P.J. Receptor-mediated dimerization of JAK2 FERM domains is required for JAK2 activation. Elife 2018, 7, e38089. [CrossRef] [PubMed]

43. De Vos, A.M.; Ultsch, M.; Kossiakoff, A.A. Human growth hormone and extracellular domain of its receptor: Crystal structure of the complex. Science 1992, 255, 306-312. [CrossRef] [PubMed]

44. Syed, R.S.; Reid, S.W.; Li, C.; Cheetham, J.C.; Aoki, K.H.; Liu, B.; Zhan, H.; Osslund, T.D.; Chirino, A.J.; Zhang, J.; et al. Efficiency of signalling through cytokine receptors depends critically on receptor orientation. Nature 1998, 395, 511-516. [CrossRef] [PubMed]

45. Dusa, A.; Mouton, C.; Pecquet, C.; Herman, M.; Constantinescu, S.N. JAK2 V617F constitutive activation requires JH2 residue F595: A pseudokinase domain target for specific inhibitors. PLoS ONE 2010, 5, e11157. [CrossRef] [PubMed]

46. Zhao, L.; Dong, H.; Zhang, C.C.; Kinch, L.; Osawa, M.; Iacovino, M.; Grishin, N.V.; Kyba, M.; Huang, L.J.S. A JAK2 interdomain linker relays epo receptor engagement signals to kinase activation. J. Biol. Chem. 2009, 284, 26988-26998. [CrossRef] [PubMed]

47. Gnanasambandan, K.; Magis, A.; Sayeski, P.P. The constitutive activation of Jak2-V617F is mediated by a $\pi$ stacking mechanism involving Phenylalanines 595 and 617. Biochemistry 2010, 49, 9972-9984. [CrossRef]

48. Anand, S.; Stedham, F.; Beer, P.; Gudgin, E.; Ortmann, C.A.; Bench, A.; Erber, W.; Green, A.R.; Huntly, B.J.P. Effects of the JAK2 mutation on the hematopoietic stem and progenitor compartment in human myeloproliferative neoplasms. Blood 2011, 118, 177-181. [CrossRef]

49. James, C.; Mazurier, F.; Dupont, S.; Chaligne, R.; Lamrissi-Garcia, I.; Tulliez, M.; Lippert, E.; Marion, F.X.; Pasquet, J.M.; Etienne, G.; et al. The hematopoietic stem cell compartment of JAK2V617F-positive myeloproliferative disorders is a reflection of disease heterogeneity. Blood 2008, 112, 2429-2438. [CrossRef]

50. Larsen, T.S.; Christensen, J.H.; Hasselbalch, H.C.; Pallisgaard, N. The JAK2 V617F mutation involves B- and T-lymphocyte lineages in a subgroup of patients with Philadelphia-chromosome negative chronic myeloproliferative disorders. Br. J. Haematol. 2007, 136, 745-751. [CrossRef]

51. Mullally, A.; Lane, S.W.; Ball, B.; Megerdichian, C.; Okabe, R.; Al-Shahrour, F.; Paktinat, M.; Haydu, J.E.; Housman, E.; Lord, A.M.; et al. Physiological Jak2V617F Expression Causes a Lethal Myeloproliferative Neoplasm with Differential Effects on Hematopoietic Stem and Progenitor Cells. Cancer Cell 2010, 17, 584-596. [CrossRef] [PubMed]

52. Li, J.; Kent, D.G.; Godfrey, A.L.; Manning, H.; Nangalia, J.; Aziz, A.; Chen, E.; Saeb-Parsy, K.; Fink, J.; Sneade, R.; et al. JAK2V617F homozygosity drives a phenotypic switch in myeloproliferative neoplasms, but is insufficient to sustain disease. Blood 2014, 123, 3139-3151. [CrossRef] [PubMed]

53. Kent, D.G.; Li, J.; Tanna, H.; Fink, J.; Kirschner, K.; Pask, D.C.; Silber, Y.; Hamilton, T.L.; Sneade, R.; Simons, B.D.; et al. SelfRenewal of Single Mouse Hematopoietic Stem Cells Is Reduced by JAK2V617F Without Compromising Progenitor Cell Expansion. PLoS Biol. 2013, 11, e100157. [CrossRef] [PubMed]

54. Vannucchi, A.M.; Antonioli, E.; Guglielmelli, P.; Rambaldi, A.; Barosi, G.; Marchioli, R.; Marfisi, R.M.; Finazzi, G.; Guerini, V.; Fabris, F.; et al. Clinical profile of homozygous JAK2 617V $>$ F mutation in patients with polycythemia vera or essential thrombocythemia. Blood 2007, 110, 840-846. [CrossRef] [PubMed]

55. Antonioli, E.; Guglielmelli, P.; Poli, G.; Bogani, C.; Pancrazzi, A.; Longo, G.; Ponziani, V.; Tozzi, L.; Pieri, L.; Santini, V.; et al. Influence of JAK2V617F allele burden on phenotype in essential thrombocythemia. Haematologica 2008, 93, 41-48. [CrossRef]

56. Michiels, J.J.; Berneman, Z.; Schroyens, W.; De Raeve, H. Changing concepts of diagnostic criteria of myeloproliferative disorders and the molecular etiology and classification of myeloproliferative neoplasms: From Dameshek 1950 to Vainchenker 2005 and beyond. Acta Haematol. 2015, 133, 36-51. [CrossRef] [PubMed]

57. Tiedt, R.; Hao-Shen, H.; Sobas, M.A.; Looser, R.; Dirnhofer, S.; Schwaller, J.; Skoda, R.C. Ratio of mutant JAK2-V617F to wild-type Jak2 determines the MPD phenotypes in transgenic mice. Blood 2008, 111, 3931-3940. [CrossRef] 
58. de Melo Campos, P.; Machado-Neto, J.A.; Eide, C.A.; Savage, S.L.; Scopim-Ribeiro, R.; da Silva Souza Duarte, A.; Favaro, P.; Lorand-Metze, I.; Costa, F.F.; Tognon, C.E.; et al. IRS2 silencing increases apoptosis and potentiates the effects of ruxolitinib in JAK2V617F-positive myeloproliferative neoplasms. Oncotarget 2016, 7, 6948-6959. [CrossRef]

59. Osorio, F.G.; Soria-Valles, C.; Santiago-Fernández, O.; Bernal, T.; Mittelbrunn, M.; Colado, E.; Rodríguez, F.; Bonzon-Kulichenko, E.; Vázquez, J.; Porta-De-La-Riva, M.; et al. Loss of the proteostasis factor AIRAPL causes myeloid transformation by deregulating IGF-1 signaling. Nat. Med. 2016, 22, 91-96. [CrossRef]

60. Fenerich, B.A.; Fernandes, J.C.; Rodrigues Alves, A.P.N.; Coelho-Silva, J.L.; Scopim-Ribeiro, R.; Scheucher, P.S.; Eide, C.A.; Tognon, C.E.; Druker, B.J.; Rego, E.M.; et al. NT157 has antineoplastic effects and inhibits IRS1/2 and STAT3/5 in JAK2(V617F)positive myeloproliferative neoplasm cells. Signal Transduct. Target. Ther. 2020, 5, 5. [CrossRef]

61. Oku, S.; Takenaka, K.; Kuriyama, T.; Shide, K.; Kumano, T.; Kikushige, Y.; Urata, S.; Yamauchi, T.; Iwamoto, C.; Shimoda, H.K.; et al. JAK2 V617F uses distinct signalling pathways to induce cell proliferation and neutrophil activation: Research paper. Br. J. Haematol. 2010, 150, 334-344. [CrossRef]

62. Lundberg, P.; Karow, A.; Nienhold, R.; Looser, R.; Hao-Shen, H.; Nissen, I.; Girsberger, S.; Lehmann, T.; Passweg, J.; Stern, M.; et al. Clonal evolution and clinical correlates of somatic mutations in myeloproliferative neoplasms. Blood 2014, 123, 2220-2228. [CrossRef] [PubMed]

63. Nangalia, J.; Nice, F.L.; Wedge, D.C.; Godfrey, A.L.; Grinfeld, J.; Thakker, C.; Massie, C.E.; Baxter, J.; Sewell, D.; Silber, Y.; et al. DNMT3A mutations occur early or late in patients with myeloproliferative neoplasms and mutation order influences phenotype. Haematologica 2015, 100, e438-e442. [CrossRef]

64. Tefferi, A.; Pardanani, A.; Lim, K.H.; Abdel-Wahab, O.; Lasho, T.L.; Patel, J.; Gangat, N.; Finke, C.M.; Schwager, S.; Mullally, A.; et al. TET2 mutations and their clinical correlates in polycythemia vera, essential thrombocythemia and myelofibrosis. Leukemia 2009, 23, 905-911. [CrossRef]

65. Abdel-Wahab, O.; Mullally, A.; Hedvat, C.; Garcia-Manero, G.; Patel, J.; Wadleigh, M.; Malinge, S.; Yao, J.J.; Kilpivaara, O.; Bhat, R.; et al. Genetic characterization of TET1, TET2, and TET3 alterations in myeloid malignancies. Blood 2009, 114, $144-147$. [CrossRef]

66. Koschmieder, S.; Chatain, N. Role of inflammation in the biology of myeloproliferative neoplasms. Blood Rev. 2020, $42,100711$. [CrossRef]

67. Czech, J.; Cordua, S.; Weinbergerova, B.; Baumeister, J.; Crepcia, A.; Han, L.; Maié, T.; Costa, I.G.; Denecke, B.; Maurer, A.; et al. JAK2V617F but not CALR mutations confer increased molecular responses to interferon- $\alpha$ via JAK1/STAT1 activation. Leukemia 2019, 33, 995-1010. [CrossRef]

68. Fleischman, A.G.; Aichberger, K.J.; Luty, S.B.; Bumm, T.G.; Petersen, C.L.; Doratotaj, S.; Vasudevan, K.B.; LaTocha, D.H.; Yang, F.; Press, R.D.; et al. TNF $\alpha$ facilitates clonal expansion of JAK2 ${ }^{\mathrm{V} 617 \mathrm{~F}}$ positive cells in myeloproliferative neoplasms. Blood 2011, 118, 6392-6398. [CrossRef]

69. Jacquelin, S.; Straube, J.; Cooper, L.; Vu, T.; Song, A.; Bywater, M.; Baxter, E.; Heidecker, M.; Wackrow, B.; Porter, A.; et al. Jak2V617F and Dnmt3a loss cooperate to induce myelofibrosis through activated enhancer-driven inflammation. Blood 2018, 118, 6392-6398. [CrossRef] [PubMed]

70. Hasselbalch, H.C. Smoking as a contributing factor for development of polycythemia vera and related neoplasms. Leuk. Res. 2015, 39, 1137-1145. [CrossRef] [PubMed]

71. Podoltsev, N.A.; Wang, X.; Wang, R.; Hofmann, J.N.; Liao, L.M.; Zeidan, A.M.; Mesa, R.; Ma, X. Lifestyle factors and risk of myeloproliferative neoplasms in the NIH-AARP diet and health study. Int. J. Cancer 2020, 147, 948-957. [CrossRef]

72. Martínez-González, M.A.; García-Arellano, A.; Toledo, E.; Salas-Salvadó, J.; Buil-Cosiales, P.; Corella, D.; Covas, M.I.; Schröder, H.; Arós, F.; Gómez-Gracia, E.; et al. A 14-item Mediterranean diet assessment tool and obesity indexes among high-risk subjects: The PREDIMED trial. PLoS ONE 2012, 7, e43134. [CrossRef] [PubMed]

73. Duncombe, A.S.; Anderson, L.A.; James, G.; de Vocht, F.; Fritschi, L.; Mesa, R.; Clarke, M.; McMullin, M.F. Modifiable Lifestyle and Medical Risk Factors Associated With Myeloproliferative Neoplasms. HemaSphere 2020, 4, e327. [CrossRef]

74. Campbell, P.J.; Scott, L.M.; Buck, G.; Wheatley, K.; East, C.L.; Marsden, J.T.; Duffy, A.; Boyd, E.M.; Bench, A.J.; Scott, M.A.; et al. Definition of subtypes of essential thrombocythaemia and relation to polycythaemia vera based on JAK2 V617F mutation status: A prospective study. Lancet 2005, 366, 1945-1953. [CrossRef]

75. Wolanskyj, A.P.; Lasho, T.L.; Schwager, S.M.; McClure, R.F.; Wadleigh, M.; Lee, S.J.; Gilliland, D.G.; Tefferi, A. JAK2V617F mutation in essential thrombocythaemia: Clinical associations and long-term prognostic relevance. Br. J. Haematol. 2005, 131, 208-213. [CrossRef]

76. Tefferi, A.; Lasho, T.L.; Schwager, S.M.; Steensma, D.P.; Mesa, R.A.; Li, C.Y.; Wadleigh, M.; Gary Gilliland, D. The JAK2V617F tyrosine kinase mutation in myelofibrosis with myeloid metaplasia: Lineage specificity and clinical correlates. Br. J. Haematol. 2005, 131, 320-328. [CrossRef]

77. Kim, D.Y.; Tariq, H.; Brown, A.F.; Vadlamudi, K.; Wang, Y.; Ikoma, S.; Holder, K.N.; Higgins, R.A.; Fan, H. JAK2 V617F Mutation Allele Burden (MAB) and Its Correlation with Hematologic Characteristics in Myeloproliferative Neoplasms. Blood 2017, $130,5267$. [CrossRef]

78. Tefferi, A.; Lasho, T.L.; Schwager, S.M.; Strand, J.S.; Elliott, M.; Mesa, R.; Li, C.-Y.; Wadleigh, M.; Lee, S.J.; Gilliland, D.G. The clinical phenotype of wild-type, heterozygous, and homozygous JAK2V617F in polycythemia vera. Cancer 2006, 106, 631-635. [CrossRef] [PubMed] 
79. Lu, X.; Huang, L.J.S.; Lodish, H.F. Dimerization by a cytokine receptor is necessary for constitutive activation of JAK2V617F. J. Biol. Chem. 2008, 283, 5258-5266. [CrossRef]

80. Lu, X.; Levine, R.; Tong, W.; Wernig, G.; Pikman, Y.; Zarnegar, S.; Gilliland, D.G.; Lodish, H. Expression of a homodimeric type I cytokine receptor is required for JAK2V617F-mediated transformation. Proc. Natl. Acad. Sci. USA 2005, 102, 18962-18967. [CrossRef]

81. James, C.; Ugo, V.; Le Couédic, J.P.; Staerk, J.; Delhommeau, F.; Lacout, C.; Garçon, L.; Raslova, H.; Berger, R.; Bennaceur-Griscelli, A.; et al. A unique clonal JAK2 mutation leading to constitutive signalling causes polycythaemia vera. Nature 2005, 434, 1144-1148. [CrossRef]

82. Laubach, J.P.; Fu, P.; Jiang, X.; Salter, K.H.; Potti, A.; Arcasoy, M.O. Polycythemia vera erythroid precursors exhibit increased proliferation and apoptosis resistance associated with abnormal RAS and PI3K pathway activation. Exp. Hematol. 2009, 37, 1411-1422. [CrossRef] [PubMed]

83. Funakoshi-Tago, M.; Tago, K.; Abe, M.; Sonoda, Y.; Kasahara, T. STAT5 activation is critical for the transformation mediated by myeloproliferative disorder-associated JAK2 V617F mutant. J. Biol. Chem. 2010, 285, 5296-5307. [CrossRef] [PubMed]

84. Grebien, F.; Kerenyi, M.A.; Kovacic, B.; Kolbe, T.; Becker, V.; Dolznig, H.; Pfeffer, K.; Klingmüller, U.; Müller, M.; Beug, H.; et al. Stat5 activation enables erythropoiesis in the absence of EpoR and Jak2. Blood 2008, 111, 4511-4522. [CrossRef] [PubMed]

85. Sachs, Z.; Been, R.A.; Decoursin, K.J.; Nguyen, H.T.; Mohd Hassan, N.A.; Noble-Orcutt, K.E.; Eckfeldt, C.E.; Pomeroy, E.J.; Diaz-Flores, E.; Geurts, J.L.; et al. Stat5 is critical for the development and maintenance of myeloproliferative neoplasm initiated by Nf1 deficiency. Haematologica 2016, 101, 1190-1199. [CrossRef]

86. Chen, E.; Beer, P.A.; Godfrey, A.L.; Ortmann, C.A.; Li, J.; Costa-Pereira, A.P.; Ingle, C.E.; Dermitzakis, E.T.; Campbell, P.J.; Green, A.R. Distinct clinical phenotypes associated with JAK2V617F reflect differential STAT1 signaling. Cancer Cell 2010, 18, 524-535. [CrossRef]

87. Huang, Z.; Richmond, T.D.; Muntean, A.G.; Barber, D.L.; Weiss, M.J.; Crispino, J.D. STAT1 promotes megakaryopoiesis downstream of GATA-1 in mice. J. Clin. Investig. 2007, 117, 3890-3899. [CrossRef]

88. Machado-Neto, J.A.; Favaro, P.; Lazarini, M.; da Silva Santos Duarte, A.; Archangelo, L.F.; Lorand-Metze, I.; Costa, F.F.; Saad, S.T.O.; Traina, F. Downregulation of IRS2 in myelodysplastic syndrome: A possible role in impaired hematopoietic cell differentiation. Leuk. Res. 2012, 36, 931-935. [CrossRef]

89. Schacher, D.H.; VanHoy, R.W.; Liu, Q.; Arkins, S.; Dantzer, R.; Freund, G.G.; Kelley, K.W. Developmental Expression of Insulin Receptor Substrate-2 During Dimethylsulfoxide-Induced Differentiation of Human HL-60 Cells. J. Immunol. 2000, 164, 113-120. [CrossRef]

90. Lima, K.; Lopes, L.R.; Machado-Neto, J.A. Exploring redox vulnerabilities in JAK2(V617F)-positive cellular models. Hematol. Transfus. Cell Ther. 2021, 43, 430-436. [CrossRef]

91. Marty, C.; Lacout, C.; Droin, N.; Le Couédic, J.P.; Ribrag, V.; Solary, E.; Vainchenker, W.; Villeval, J.L.; Plo, I. A role for reactive oxygen species in JAK2 V617F myeloproliferative neoplasm progression. Leukemia 2013, 27, 2187-2195. [CrossRef]

92. Vener, C.; Novembrino, C.; Bamonti Catena, F.; Fracchiolla, N.S.; Gianelli, U.; Savi, F.; Radaelli, F.; Fermo, E.; Cortelezzi, A.; Lonati, S.; et al. Oxidative stress is increased in primary and post-polycythemia vera myelofibrosis. Exp. Hematol. 2010, 38, 1058-1065. [CrossRef]

93. Hurtado-Nedelec, M.; Csillag, M.J.G.; Boussetta, T.; Belambri, S.A.; Fay, M.; Cassinat, B.; Gougerot, M.A.P.; Dang, P.M.C.; El-Benna, J. Increased reactive oxygen species production and p47phox phosphorylation in neutrophils from myeloproliferative disorders patients with JAK2 (V617F) mutation. Haematologica 2013, 98, 1517-1524. [CrossRef]

94. Allahverdi, N.; Yassin, M.; Ibrahim, M. Environmental Factors, Lifestyle Risk Factors, and Host Characteristics Associated With Philadelphia Negative Myeloproliferative Neoplasm: A Systematic Review. Cancer Control 2021, 28, 10732748211046802. [CrossRef]

95. Chen, C.C.; You, J.Y.; Lung, J.; Huang, C.E.; Chen, Y.Y.; Leu, Y.W.; Ho, H.Y.; Li, C.P.; Lu, C.H.; Der Lee, K.; et al. Aberrant let7a/HMGA2 signaling activity with unique clinical phenotype in JAK2-mutated myeloproliferative neoplasms. Haematologica 2017, 102, 509-518. [CrossRef]

96. Uras, I.Z.; Maurer, B.; Nivarthi, H.; Jodl, P.; Kollmann, K.; Prchal-Murphy, M.; Milosevic Feenstra, J.D.; Zojer, M.; Lagger, S.; Grausenburger, R.; et al. CDK6 coordinates JAK2V617F mutant MPN via NF-kB and apoptotic networks. Blood 2019, 133, 1677-1690. [CrossRef]

97. Catherwood, M.A.; McAllister, R.; McCallion, P.; McGimpsey, J.E.; Hindley, A.; Feerick, J.; Greenfield, G.; Kennedy, P.; Benson, G.; Arnold, C.; et al. A molecular diagnostic algorithm for JAK2 V617F investigations in suspected myeloproliferative neoplasms. Ir. J. Med. Sci. 2020, 189, 621-626. [CrossRef]

98. McPherson, S.; McMullin, M.F.; Mills, K. Epigenetics in Myeloproliferative Neoplasms. J. Cell. Mol. Med. 2017, 21, 1660-1667. [CrossRef] [PubMed]

99. Milosevic, J.D.; Kralovics, R. Genetic and epigenetic alterations of myeloproliferative disorders. Int. J. Hematol. 2012, 97, 183-197. [CrossRef] [PubMed]

100. Ortmann, C.A.; Kent, D.G.; Nangalia, J.; Silber, Y.; Wedge, D.C.; Grinfeld, J.; Baxter, E.J.; Massie, C.E.; Papaemmanuil, E.; Menon, S.; et al. Effect of Mutation Order on Myeloproliferative Neoplasms. N. Engl. J. Med. 2015, 372, 601-612. [CrossRef] [PubMed] 
101. Chen, E.; Schneider, R.K.; Breyfogle, L.J.; Rosen, E.A.; Poveromo, L.; Elf, S.; Ko, A.; Brumme, K.; Levine, R.; Ebert, B.L.; et al. Distinct effects of concomitant Jak2V617F expression and Tet2 loss in mice promote disease progression in myeloproliferative neoplasms. Blood 2015, 125, 327-335. [CrossRef] [PubMed]

102. Staehle, H.F.; Heinemann, J.; Gruender, A.; Omlor, A.M.; Pahl, H.L.; Jutzi, J.S. Jmjd1c is dispensable for healthy adult hematopoiesis and Jak2V617F-driven myeloproliferative disease initiation in mice. PLoS ONE 2020, 15, e228362. [CrossRef]

103. McKenney, A.S.; Lau, A.N.; Hanasoge Somasundara, A.V.; Spitzer, B.; Intlekofer, A.M.; Ahn, J.; Shank, K.; Rapaport, F.T.; Patel, M.A.; Papalexi, E.; et al. JAK2/IDH-mutant-driven myeloproliferative neoplasm is sensitive to combined targeted inhibition. J. Clin. Investig. 2018, 128, 789-804. [CrossRef] [PubMed]

104. Zhang, S.J.; Rampal, R.; Manshouri, T.; Patel, J.; Mensah, N.; Kayserian, A.; Hricik, T.; Heguy, A.; Hedvat, C.; Gönen, M.; et al. Genetic analysis of patients with leukemic transformation of myeloproliferative neoplasms shows recurrent SRSF2 mutations that are associated with adverse outcome. Blood 2012, 119, 4480-4485. [CrossRef]

105. Anthony Green, P.B. Somatic mutations of IDH1 and IDH2 in the leukemic transformation of myeloproliferative neoplasms. $N$. Engl. J. Med. 2010, 362, 369-370. [CrossRef] [PubMed]

106. Ji, Z.; He, L.; Regev, A.; Struhl, K. Inflammatory regulatory network mediated by the joint action of NF-kB, STAT3, and AP-1 factors is involved in many human cancers. Proc. Natl. Acad. Sci. USA 2019, 116, 9453-9462. [CrossRef]

107. Coussens, L.M.; Werb, Z. Inflammation and cancer. Nature 2002, 420, 860-867. [CrossRef]

108. Bolton-Gillespie, E.; Schemionek, M.; Klein, H.U.; Flis, S.; Hoser, G.; Lange, T.; Nieborowska-Skorska, M.; Maier, J.; Kerstiens, L.; Koptyra, M.; et al. Genomic instability may originate from imatinib-refractory chronic myeloid leukemia stem cells. Blood 2013, 121, 4175-4183. [CrossRef]

109. Chen, E.; Ahn, J.S.; Sykes, D.B.; Breyfogle, L.J.; Godfrey, A.L.; Nangalia, J.; Ko, A.; DeAngelo, D.J.; Green, A.R.; Mullally, A. RECQL5 Suppresses Oncogenic JAK2-Induced Replication Stress and Genomic Instability. Cell Rep. 2015, 13, 2345-2352. [CrossRef]

110. Holmström, M.O.; Hjortsø, M.D.; Ahmad, S.M.; Met, Ö.; Martinenaite, E.; Riley, C.; Straten, P.; Svane, I.M.; Hasselbalch, H.C.; Andersen, M.H. The JAK2V617F mutation is a target for specific T cells in the JAK2V617F-positive myeloproliferative neoplasms. Leukemia 2017, 31, 495-498. [CrossRef]

111. Hinds, D.A.; Barnholt, K.E.; Mesa, R.A.; Kiefer, A.K.; Do, C.B.; Eriksson, N.; Mountain, J.L.; Francke, U.; Tung, J.Y.; Nguyen, H.M.; et al. Germ line variants predispose to both JAK2 V617F clonal hematopoiesis and myeloproliferative neoplasms. Blood 2016, 128, 1121-1128. [CrossRef]

112. Passamonti, F.; Rumi, E.; Pietra, D.; Lazzarino, M.; Cazzola, M. JAK2 (V617F) mutation in healthy individuals. Br. J. Haematol. 2007, 136, 678-679. [CrossRef]

113. Williams, N.; Lee, J.; Moore, L.; Baxter, J.E.; Hewinson, J.; Dawson, K.J.; Menzies, A.; Godfrey, A.L.; Green, A.R.; Campbell, P.J.; et al. Driver mutation acquisition in utero and childhood followed by lifelong clonal evolution underlie myeloproliferative neoplasms. Blood 2020, 136, LBA-1. [CrossRef]

114. Williams, N.; Lee, J.; Moore, L.; Baxter, E.J.; Hewinson, J.; Dawson, K.J.; Menzies, A.; Godfrey, A.L.; Green, A.R.; Campbell, P.J.; et al. Phylogenetic reconstruction of myeloproliferative neoplasm reveals very early origins and lifelong evolution. bioRxiv 2020. [CrossRef]

115. Van Egeren, D.; Escabi, J.; Nguyen, M.; Liu, S.; Reilly, C.R.; Patel, S.; Kamaz, B.; Kalyva, M.; DeAngelo, D.J.; Galinsky, I.; et al. Reconstructing the lineage histories and differentiation trajectories of individual cancer cells in JAK2-mutant myeloproliferative neoplasms. bioRxiv 2020, 1-10. [CrossRef]

116. Godfrey, A.L.; Chen, E.; Pagano, F.; Silber, Y.; Campbell, P.J.; Green, A.R. Clonal analyses reveal associations of JAK2V617F homozygosity with hematologic features, age and gender in polycythemia vera and essential thrombocythemia. Haematologica 2013, 98, 718-721. [CrossRef] [PubMed]

117. Leal, A.D.; Thompson, C.A.; Wang, A.H.; Vierkant, R.A.; Habermann, T.M.; Ross, J.A.; Mesa, R.A.; Virnig, B.A.; Cerhan, J.R. Anthropometric, medical history and lifestyle risk factors for myeloproliferative neoplasms in the Iowa Women's Health Study cohort. Int. J. Cancer 2014, 134, 1741-1750. [CrossRef] [PubMed]

118. Lindholm Sørensen, A.; Hasselbalch, H.C. Smoking and philadelphia-negative chronic myeloproliferative neoplasms. Eur. J. Haematol. 2016, 97, 63-69. [CrossRef]

119. Tefferi, A.; Wassie, E.A.; Lasho, T.L.; Finke, C.; Belachew, A.A.; Ketterling, R.P.; Hanson, C.A.; Pardanani, A.; Gangat, N.; Wolanskyj, A.P. Calreticulin mutations and long-term survival in essential thrombocythemia. Leukemia 2014, 28, $2300-2303$. [CrossRef]

120. Rumi, E.; Pietra, D.; Ferretti, V.; Klampfl, T.; Harutyunyan, A.S.; Milosevic, J.D.; Them, N.C.C.; Berg, T.; Elena, C.; Casetti, I.C.; et al. JAK2 or CALR mutation status defines subtypes of essential thrombocythemia with substantially different clinical course and outcomes. Blood 2014, 123, 1544-1551. [CrossRef]

121. Li, J.; Spensberger, D.; Ahn, J.S.; Anand, S.; Beer, P.A.; Ghevaert, C.; Chen, E.; Forrai, A.; Scott, L.M.; Ferreira, R.; et al. JAK2 V617F impairs hematopoietic stem cell function in a conditional knock-in mouse model of JAK2 V617F-positive essential thrombocythemia. Blood 2010, 116, 1528-1538. [CrossRef] [PubMed] 